\title{
Health promoting properties of Alternanthera brasiliana leaves and Hibiscus sabdariffa calyces used in fortification of maize-bambara groundnut malt and maize-cowpea malt complementary foods
}

\author{
${ }^{1 *}$ Attaugwu R. N. and ${ }^{2}$ Uvere P. O. \\ ${ }^{1}$ Department of Food Science and Technology, Madonna University Nigeria, Akpugo, Enugu State, \\ Nigeria \\ ${ }^{2}$ Department of Food Science and Technology, University of Nigeria, Nsukka, Nigeria
}

\begin{abstract}
Article history:
Received: 24 May 2017

Received in revised form: 11 June 2017

Accepted: 14 June 2017

Available Online: 16 June 2017

Keywords:

Alternanthera brasiliana

leaves,

Hibiscus sabdariffa calyces, Antioxidant activity, Health promoting components.
\end{abstract}

DOI:

http://doi.org/10.26656/ fr.2017.4.058

\begin{abstract}
The study evaluated the chemical and antioxidant properties of Alternanthera brasiliana leaves and Hibiscus sabdariffa calyces used in iron and zinc fortification of maizebambara groundnut malt and maize-cowpea malt complementary foods. A. brasiliana leaves and $H$. sabdariffa calyces were freshly harvested, dried at $50^{\circ} \mathrm{C}$ for 48 hours and analyzed for the relevant chemical components and antioxidant activities. The vitamin A content was 6996 and $745.6 \mu \mathrm{gRE} / \mathrm{kg}$ while the vitamin $\mathrm{C}$ was 238.26 and $294.78 \mathrm{mg} / \mathrm{kg}$ respectively. The aqueous extracts of $A$. brasiliana and $H$. sabdariffa calyces contained $509.5 \mathrm{mg} / \mathrm{kg}$ and $5234.72 \mathrm{mg} / \mathrm{kg}$ of alkaloids, $1545 \mathrm{mg} / \mathrm{kg}$ and $384 \mathrm{mg} / \mathrm{kg}$ of anthocyanins, 767.3 and $235.83 \mathrm{mg} / \mathrm{kg}$ of carotenoids, $14,702.8$ and $26,428.3 \mathrm{mg} / \mathrm{kg}$ of phenols, 1043.5 and $897.63 \mathrm{mg} / \mathrm{kg}$ steroids and $462.0 \mathrm{mg} / \mathrm{kg}$ and $1006.5 \mathrm{mg} / \mathrm{kg}$ of flavonoids respectively. A. brasiliana and $H$. sabdariffa extracts had concentration-dependent DPPH activity with $\mathrm{IC}_{50}$ of $1.76 \mathrm{mg} / \mathrm{ml}$ and $5.745 \mathrm{mg} / \mathrm{ml}$, nitric oxide scavenging activity with $\mathrm{IC}_{50}$ of 0.675 $\mathrm{mg} / \mathrm{ml}$ and $3.976 \mathrm{mg} / \mathrm{ml}$ while the ferric reducing power had an absorbance range of $0.5-$ 0.982 and $0.959-0.986$ respectively. The study revealed that A.brasiliana leaves and $H$. sabdariffa calyces contain components that will impact positively on the health of the infants when used to formulate complementary foods.
\end{abstract}

\section{Introduction}

The role of diet and nutrition as determinants of chronic disease is well documented (Middleton et al., 2000; Yi-fang, 2002) and there is growing evidence that chemical components of plants and microbial foods may play an integral role in the link between food and longterm health (Ferrari, 2004). Complementary foods are any nutrient containing food given to young children along with breast-milk (Gibbs, 2010) when the breast milk nutrients become inadequate for their energy and growth needs (WHO, 2003) within the $6-23$ months window. It is required to ensure adequate growth, to prevent malnutrition, stunting, and anaemia (Bhasin et al., 2003). Poor complementary feeding is the immediate direct cause of malnutrition [which manifests as protein energy malnutrition (PEM) and micronutrient deficiencies] leading to growth faltering and high rates of infections during infancy.

In most traditional cultures of the developing world, cereal-based gruels are the first complementary foods to be introduced to infants, sometime between 4 and 6 months of age. They are followed by vegetables, fruits, fruit juices, and meat products. These plant-based traditional complementary foods do not meet these nutritional requirements because they are deficient in micronutrients such as calcium, iron, zinc and vitamin A (Dewey and Brown, 2003). This is because the level of these micronutrients falls below the Recommended Dietary Allowance (RDA) of $50 \mathrm{~g} / \mathrm{kg}$ for calcium, 275 $\mathrm{mg} / \mathrm{kg}$ for iron, $125 \mathrm{mg} / \mathrm{kg}$ for zinc and $5000 \mu \mathrm{gRE} / \mathrm{kg}$ for vitamin A. Hence, calcium, iron, zinc and vitamin A deficiencies continue to pose great danger to 6-12 months old infants leading to increased susceptibility to 
infections such as diarrhea, cholera and impaired immunity (Lutter and Dewey, 2003).

In infants, iron and zinc requirements are difficult to meet from non-fortified complementary foods (WHO/UNICEF, 2003). These can be prevented by fortification of infant foods. Fortification of plantbased complementary foods with vitamin and mineral pre-mix or animal supplements such as milk makes the foods expensive for low-income earners who earn less than 300 naira (1.5 USD) per day (Anon., 2012). The alternative is to adopt food-to-food fortification. This has fueled the interest in plant foods as sources of micronutrients for combating micronutrient deficiency of chemicals that may have useful roles in the health of infants. The suitability of a complementary food depends on a number of factors including the nature of raw materials and methods of processing and fortification practices adopted.

Alternanthera brasiliana (L) O. Kuntze belongs to the Family Amaranthaceae commonly known in Brazil as joy weed or Josephs coat is widely used as a medicinal agent to cure different disease, such as inflammation, wound healing, analgesic, antitumor activity, immune modulator and lymphocyte proliferation (Duarte and Debur, 2004; Saawan et al., 2011). Roselle (Hibiscus sabdariffa L.) on the other hand belongs to the Family Malvaceae and is known in Nigeria as "Zobo". It is used effectively in folk medicines for the treatment of hypertension, inflammatory diseases and cancer (Kong et al., 2003; Lin et al., 2007), decrease blood viscosity and reduce hypertension (Christian et al., 2006).

Apart from these properties, there is evidence that the calyces of Hibiscus sabdariffa can be used in food-to-food- fortification to boost the iron and zinc contents in maize-bambara groundnut malt and maizecowpea malt complementary foods (Attaugwu, 2015). It is against this background that the health promoting properties of Hibiscus sabdariffa and Alternanthera brasiliana which is known to have good iron and zinc contents were investigated.

\section{Materials and methods}

\subsection{Materials}

Fresh leaves of Brazilian joy weed [Alternanthera brasiliana (L.) O. Kuntze] and calyces of Roselle [Hibiscus sabdariffa (L.) malvaceae] was obtained from a farm in the University of Nigeria Nsukka.

\subsection{Methods}

One thousand grams (1000 g) of freshly harvested $A$. brasiliana leaves and $H$. sabdariffa calyces were chopped into $2 \mathrm{~mm}$ slices and dried at $50^{\circ} \mathrm{C}$ in a convection Gallenkamp oven (Model IH-150, Gallenkamp, London, England). The extracts for the free radical scavenging activities were prepared according to the method described by Oyedemi et al. (2010) with a slight modification of using ethanol for extraction instead of methanol.

\subsection{Analysis}

The steroid content, total carotenoid, ascorbic acid, thiamine, riboflavin, niacinamide, pyridoxine hydrochloride and cobalamin contents were determined using the method as described in AOAC (2010). The vitamin $\mathrm{E}$ content of the samples was determined by the $\alpha, \alpha$-dipyridyl method of Pearson (1976). The vitamin K content of the samples was determined by the 2, 4dinitrophenyhydrazine method of Snell and Snell (1953). The flavonoid and alkaloid contents were determined using the method of Harborne (1973). The total phenolic content in the aqueous extracts $(1: 4 \mathrm{w} / \mathrm{v})$ of dried $A$. brasiliana leaves and dried $H$. sabdariffa calyces were determined using the method of Wolfe et al. (2003). Total flavonoids were determined by the method of Ordoñez et al. (2006). Total flavonol content was determined by the spectrophotometric procedure described by Kumaran and Karunakaran (2007). Total proanthocyanidin determination was based on the spectrophotometric procedure of Sun et al. (1998). The DPPH and nitric oxide free radical scavenging activities were determined by the methods of Liyana-Pathiranan and Shahidi (2005) and Oyedemi et al. (2010) respectively. The ferric oxide reducing power of the ethanolic extract was evaluated according to the spectrophotometric method of Yen and Chen (1995).

\section{Results and discussion}

\subsection{Vitamin composition of A. brasiliana leaves and $H$.} sabdariffa calyces

The vitamin composition of $A$. brasiliana leaves and $H$. sabdariffa calyces are presented in Table 1 . The vitamin A content of $A$. brasiliana and $H$. sabdariffa calyces were $6996 \mu \mathrm{gRE} / \mathrm{kg}$ and $745.6 \mu \mathrm{gRE} / \mathrm{kg}$ respectively. The vitamin A content of $A$. brasiliana leaves and $H$. sabdariffa calyces are above the RDA 
requirement of $500 \mu \mathrm{gRE} / \mathrm{kg}$ in complementary foods (Lutter and Dewey, 2003) implying that they could be a good source of vitamin A which is needed for good vision in infants. Hence the use of $A$. brasiliana leaves and $H$. sabdariffa calyces in complementary foods could improve the vision of infants taking the food. Saawan et al. (2011) reported $19260 \mu \mathrm{g} / \mathrm{kg}$ pro-vitamin A carotenoids in A. brasiliana.

Table 1. Vitamin composition of $A$. brasiliana leaves and $H$. sabdariffa calyces

\begin{tabular}{lcc}
\hline Micronutrient & A. brasiliana & H. sabdariffa \\
\hline $\begin{array}{l}\text { Vitamin A } \\
(\mu \mathrm{gRE} / \mathrm{kg})\end{array}$ & $6996.00 \pm 0.0167^{\mathrm{b}}$ & $745.60 \pm 0.0042^{\mathrm{a}}$ \\
$\mathrm{B}_{1}(\mathrm{mg} / \mathrm{kg})$ & $11.12 \pm 0.0551^{\mathrm{a}}$ & $12.37 \pm 0.0045^{\mathrm{b}}$ \\
$\mathrm{B}_{2}(\mathrm{mg} / \mathrm{kg})$ & $654.10 \pm 0.0318^{\mathrm{a}}$ & $4094.50 \pm 0.0271^{\mathrm{b}}$ \\
$\mathrm{B}_{3}(\mathrm{mg} / \mathrm{kg})$ & $4184.40 \pm 0.0242^{\mathrm{b}}$ & $2163.10 \pm .0324^{\mathrm{a}}$ \\
$\mathrm{B}_{6}(\mathrm{mg} / \mathrm{kg})$ & $21.01 \pm .0009^{\mathrm{a}}$ & $8.32 \pm 0.0042^{\mathrm{b}}$ \\
$\mathrm{B}_{12}(\mathrm{mg} / \mathrm{kg})$ & $1.44 \pm .0015^{\mathrm{a}}$ & $43.80 \pm 0.0057^{\mathrm{b}}$ \\
$\mathrm{C}(\mathrm{mg} / \mathrm{kg})$ & $238.36 \pm 0.0159^{\mathrm{a}}$ & $294.78 \pm 0.0411^{\mathrm{b}}$ \\
\hline
\end{tabular}

Results are the means of three replications. Values carrying different superscript in the same row are significantly different $(\mathrm{p}<0.05)$

The vitamin B1 (thiamin) content of $A$. brasiliana and $H$. sabdariffa were $11.12 \mathrm{mg} / \mathrm{kg}$ and $12.37 \mathrm{mg} / \mathrm{kg}$ respectively. The vitamin $\mathrm{B}_{1}$ content of $H$. sabdariffa of this report is higher than the 1.23 and $1.77 \mathrm{mg} / \mathrm{kg}$ reported by Luvonga et al. (2012) for fresh and dried $H$. sabdariffa respectively. The differences may be attributed to genetic variety and type of soil. These results implied that infants consuming these foods will have an improved appetite, a healthier nervous system and a higher release of energy from the complementary foods as these are the major functions of vitamin $B_{1}$ (thiamin) in the body.

The vitamin $\mathrm{B}_{2}$ (riboflavin) content of $A$. brasiliana and $H$. sabdariffa were $654 \mathrm{mg} / \mathrm{kg}$ and $4094.50 \mathrm{mg} / \mathrm{kg}$ respectively. The vitamin $\mathrm{B}_{2}$ content of $A$. brasiliana was higher than the $140 \mathrm{mg} / \mathrm{kg}$ content reported by Saawan et al. (2011). The differences may be attributed to genetic variety and type of soil. Vitamin $\mathrm{B}_{2}$ (riboflavin) is responsible for maintaining healthy blood cells, plays an important role in the conversion of food into energy and in fat and protein metabolism. Hence, infants consuming complementary foods containing $A$. brasiliana and $H$. sabdariffa will have healthy blood cells, healthier vision and skin as well as improved fat and protein metabolism.

The vitamin $\mathrm{B}_{3}$ (niacin) content of $A$. brasiliana leaves and $H$. sabdariffa calyces were $4184.40 \mathrm{mg} / \mathrm{kg}$ and $1216.31 \mathrm{mg} / \mathrm{kg}$ respectively. The vitamin $\mathrm{B}_{3}$ content of $A$. brasiliana in this report was lower than the 12,000 $\mathrm{mg} / \mathrm{kg}$ reported by Saawan et al. (2011) for $A$. brasiliana. The differences may be attributed to genetic variety and type of soil. However, the vitamin $\mathrm{B}_{3}$ content of $H$. sabdariffa $(1216.31 \mathrm{mg} / \mathrm{kg})$ of this report was higher than the $37.7 \mathrm{mg} / \mathrm{kg}$ reported by Wong et al. (2002) for $H$. sabdariffa. The difference in the vitamin $\mathrm{B}_{3}$ content of the present report could be attributed to genetic variety and geographic differences. Vitamin $\mathrm{B}_{3}$ helps in lowering the level of bad cholesterol and elevation of good (HDL) cholesterol level leading to significant decrease in heart disease. It also offers protection for certain skin cancers.

The vitamin $\mathrm{B}_{6}$ content of $A$. brasiliana leaves and H. sabdariffa calyces were $21.01 \mathrm{mg} / \mathrm{kg}$ and. $8.32 \mathrm{mg} /$ $\mathrm{kg}$ respectively. The high vitamin $\mathrm{B}_{6}$ content of $A$. brasiliana and $H$. sabdariffa implies that the use of $A$. brasiliana leaves and $H$. sabdariffa calyces in complementary foods will help in fighting anemia in children if consumed since the health benefits of vitamin $\mathrm{B}_{6}$ includes stimulating co-enzymatic activities, positive effect on hormone control, cardiac diseases, kidney disorder and anemia.

The vitamin $\mathrm{C}$ content of $A$. brasiliana leaves and H. sabdariffa calyces were $238.36 \mathrm{mg} / \mathrm{kg}$ and 294.78 $\mathrm{mg} / \mathrm{kg}$ respectively. The vitamin $\mathrm{C}$ content of $A$. brasiliana $(238.36 \mathrm{mg} / \mathrm{kg})$ was higher than the $170 \mathrm{mg} /$ $\mathrm{kg}$ content reported by Saawan et al. (2011) while that of $H$. sabdariffa $(294.78 \mathrm{mg} / \mathrm{kg})$ was higher than 67.01 and $49.90 \mathrm{mg} / \mathrm{kg}$ reported by Luvonga et al. (2012) for fresh and dried H. sabdariffa. The difference could be attributed to genetic variety and type of soil. The high vitamin $\mathrm{C}$ content of the samples could enhance nonheme iron absorption from the fortified complementary foods hence reduce the prevalence of anemia in the infants consuming it. It will also help in fighting some cancers as vitamin $\mathrm{C}$ is a known antioxidant.

\subsection{Phytochemical composition of A. brasiliana and $H$. sabdariffa calyces}

The phytochemical composition of aqueous extracts of $A$. brasiliana leaves and $H$. sabdariffa calyces are presented in Table 2. The alkaloid content of aqueous extracts of $A$. brasiliana leaves and $H$. sabdariffa 
calyces were $509.5 \mathrm{mg} / \mathrm{kg}$ and $5234.72 \mathrm{mg} / \mathrm{kg}$ respectively. The anthocyanin content of $A$. brasiliana leaves and $H$. sabdariffa calyces aqueous extracts were $1545 \mathrm{mg} / \mathrm{kg}$ and $384 \mathrm{mg} / \mathrm{kg}$ respectively. The phenolic contents of aqueous extracts of $A$. brasiliana leaves and $H$. sabdariffa calyces were $14,702.80 \mathrm{mg} / \mathrm{kg}$ and $26,428.30 \mathrm{mg} / \mathrm{kg}$ respectively. The flavonoid content of extracts of $A$. brasiliana leaves and $H$. sabdariffa calyces were $462.00 \mathrm{mg} / \mathrm{kg}$ and $1006.50 \mathrm{mg} / \mathrm{kg}$ respectively. The carotenoid contents of the plant extracts were $767.30 \mathrm{mg} /$ $\mathrm{kg}$ and $235.83 \mathrm{mg} / \mathrm{kg}$ for $A$. brasiliana leaves and $H$. sabdariffa calyces respectively. Saawan et al. (2011) reported $19.26 \mathrm{mg} / \mathrm{kg}$ carotenoids in A. brasiliana leaves while Wong et al. (2002) reported $0.3 \mathrm{mg} / \mathrm{kg}$ carotenoid content in $H$. sabdariffa calyces. The steroid content of A. brasiliana leaves and $H$. sabdariffa calyces were $1043.50 \mathrm{mg} / \mathrm{kg}$ and $897.63 \mathrm{mg} / \mathrm{kg}$ respectively. $H$. sabdariffa calyces had $4725.2 \mathrm{mg} / \mathrm{kg}$ higher alkaloid content than $A$. brasiliana leaves. The anthocyanin content of $A$. brasiliana was $1161 \mathrm{mg} / \mathrm{kg}$ higher than that of $H$. sabdariffa. A. brasiliana leaves would have more antioxidant/ health promoting benefit than $H$. sabdariffa calyces. The phenolic content of $H$. sabdariffa was $11,725.50 \mathrm{mg} / \mathrm{kg}$ higher than that of $A$. brasiliana. This suggests that the $H$. sabdariffa extract will possess higher antioxidant activity than $A$. brasiliana. The flavonoid content of $H$. sabdariffa calyces was 544.50 $\mathrm{mg} / \mathrm{kg}$ higher than that of $A$. brasiliana leaves. This could be attributed to the fact that flowers generally have more flavonoids which are the most important pigments for flower and petal coloration and are used mainly for the attraction of pollinator animals. The result of this study is similar to that of Elija et al. (2010) who reported higher flavonoid content in flowers of Ipomoea carnea than in the stem and leaves antioxidant effects of which are attributed to their redox properties. They are therefore reducing agents, hydrogen donors, singlet oxygen quenchers and metal- chelators (VladimirKnezevic et al., 2011), properties which could contribute to their potential role in the prevention of cancer and heart disease.

\subsection{Antioxidant properties}

The antioxidant activities of ethanolic extracts of dried Alternanthera brasiliana leaves and Hibiscus sabdariffa calyces are illustrated in Figures 1, 2 and 3.

Proanthocyanidins, vitamin $\mathrm{C}$ and phenols content have been reported to have high antioxidant activity (Oyademi et al., 2010; Azza et al., 2011). The DPPH activity of $A$. brasiliana increased with increasing concentration of extract while that of $H$. sabdariffa decreased with increasing concentration of extract. The latter could be due to exhaustion of $\mathrm{DPPH}$ reacting species at a lower concentration of extract or, due to the acidic $\mathrm{pH}$ of the extract (Luvonga et al., 2012). A similar result of decrease has been reported by Luvonga et al. (2012).

Table 2. Phytochemical composition of $A$. brasiliana leaves and $H$. sabdariffa calyces

Results are the means of three replications. Values carrying

\begin{tabular}{|c|c|c|}
\hline $\begin{array}{l}\text { Phytochemical } \\
\text { composition }\end{array}$ & $\begin{array}{l}\text { A. brasiliana } \\
(\mathrm{mg} / \mathrm{kg})\end{array}$ & $\begin{array}{l}\text { H. sabdariffa } \\
(\mathrm{mg} / \mathrm{kg})\end{array}$ \\
\hline Alkaloids & $\begin{array}{c}509.50 \pm \\
0.0531^{\mathrm{a}}\end{array}$ & $\begin{array}{c}52,347.20 \pm \\
0.1089^{b}\end{array}$ \\
\hline Anthocyanin & $\begin{array}{c}1545.00 \pm \\
0.0473^{\mathrm{b}}\end{array}$ & $\begin{array}{c}384.00 \pm \\
0.0300^{\mathrm{a}}\end{array}$ \\
\hline Carotenoids & $\begin{array}{l}767.30 \pm \\
0.0410^{\mathrm{b}}\end{array}$ & $\begin{array}{c}235.803 \pm \\
0.0111^{\mathrm{a}}\end{array}$ \\
\hline Steroids & $\begin{array}{c}1043.50 \pm \\
0.0234^{\mathrm{b}}\end{array}$ & $\begin{array}{c}897.63 \pm \\
0.0762^{\mathrm{a}}\end{array}$ \\
\hline Phenols & $\begin{array}{c}14,702.40 \pm \\
0.0212^{\mathrm{a}}\end{array}$ & $\begin{array}{c}26,428.33 \pm \\
0.0122^{b}\end{array}$ \\
\hline Flavonoids & $\begin{array}{c}462.00 \pm \\
0.0891^{\mathrm{a}}\end{array}$ & $\begin{array}{c}1006.50 \pm \\
0.0140^{\mathrm{b}}\end{array}$ \\
\hline $\begin{array}{c}\text { Total phenol }(\mathrm{mg} / \mathrm{kg} \\
\text { gallic acid) }\end{array}$ & $\begin{array}{c}67,320.00 \pm \\
0.0222^{\mathrm{a}}\end{array}$ & $\begin{array}{l}67,440.00 \\
\pm 0.0341^{\mathrm{b}}\end{array}$ \\
\hline $\begin{array}{l}\text { Total flavonoids (mg/ } \\
\text { kg quercetin } \\
\text { equivalent) }\end{array}$ & $\begin{array}{c}69,030.00 \pm \\
0.0541^{\mathrm{b}}\end{array}$ & $\begin{array}{l}57,810.00 \\
\pm 0.0751^{\mathrm{a}}\end{array}$ \\
\hline $\begin{array}{c}\text { Total flavonols (mg/ } \\
\text { kg quercetin } \\
\text { equivalent) }\end{array}$ & $\begin{array}{c}50,430.00 \pm \\
0.0323^{\mathrm{b}}\end{array}$ & $\begin{array}{l}8710.00 \\
\pm 0.0211^{\mathrm{a}}\end{array}$ \\
\hline $\begin{array}{l}\text { Proanthocyanidins } \\
\mathrm{mg} / \mathrm{kg} \text { catechin } \\
\text { equivalent) }\end{array}$ & $\begin{array}{c}461,340.00 \pm \\
0.0412^{\mathrm{a}}\end{array}$ & $\begin{array}{c}729,290.00 \pm \\
0.0122^{\mathrm{b}}\end{array}$ \\
\hline
\end{tabular}

different superscripts in the same row are significantly different $(\mathrm{p}<0.05)$

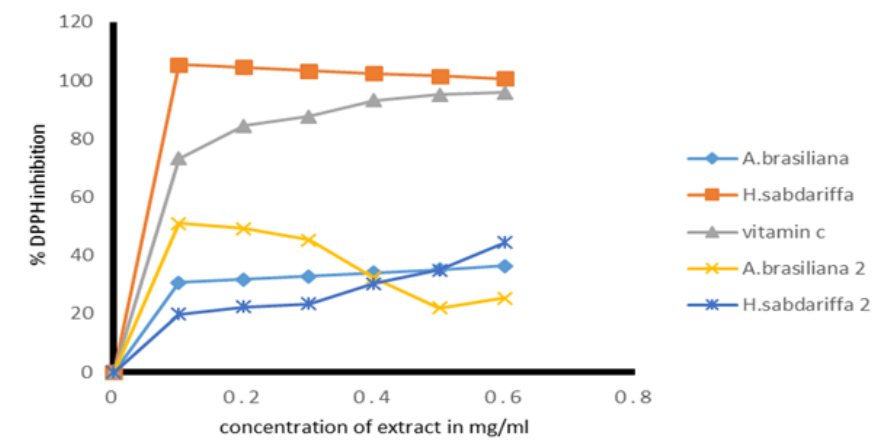

Figure 1. DPPH scavenging activity of $A$. brasiliana and $H$. sabdariffa extracts. A . brasiliana = Alternanthera brasiliana extract, H. sabdariffa = Hibiscus sabdariffa extract, Vitamin $\mathrm{C}=$ Vitamin $\mathrm{C}, \mathrm{A}$. brasiliana 2 = Alternanthera brasiliana extract adjusted with $\mathrm{NaOH}, H$. sabdariffa $2=$ Hibiscus sabdariffa extract adjusted with $\mathrm{NaOH}$. 


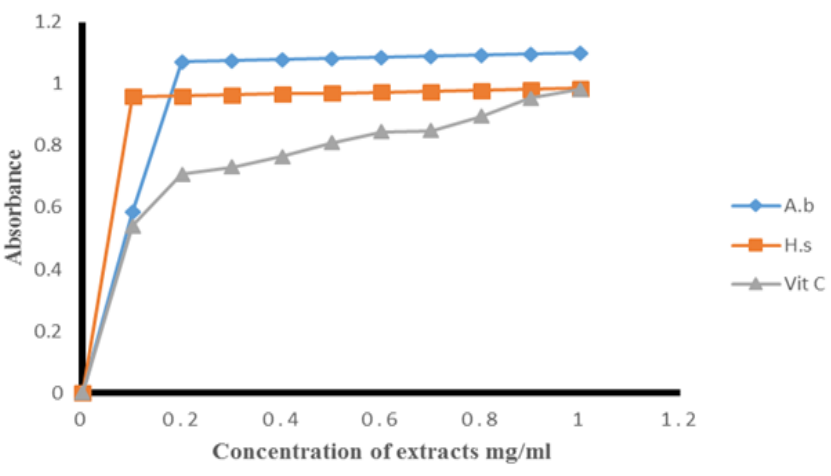

Figure 2. Ferric oxide reducing power of $A$. brasiliana and H. sabdariffa extracts. A.b = Alternanthera brasiliana extract, H.s = Hibiscus sabdariff aextract, Vit $\mathrm{C}=$ Vitamin C.

The abilities of the extracts to scavenge DPPH radicals (Figure 1) showed that $A$. brasiliana and $H$. sabdariffa extracts had DPPH radical scavenging activity with $\mathrm{IC}_{50}$ of $1.76 \mathrm{mg} / \mathrm{ml}$ and $5.745 \mathrm{mg} / \mathrm{ml}$ respectively. The DPPH activity of $A$. brasiliana and $H$. sabdariffa extracts were lower than the $\mathrm{IC}_{50}$ of $0.088 \mathrm{mg} / \mathrm{ml}$ for vitamin $\mathrm{C}$, the reference antioxidant. Although the $\mathrm{IC}_{50}$ of $A$. brasiliana was higher than the $\mathrm{IC}_{50}$ of $H$. sabdariffa, which at a low concentration of $0.1 \mathrm{mg} / \mathrm{ml}$ inhibited $105.54 \%$ of DPPH radicals. This decreased gradually to $1.5 \%$ at $10.05 \mathrm{mg} / \mathrm{ml}$ implying that $H$. sabdariffa possesses higher DPPH activity than $A$. brasiliana extract. The higher DPPH activity of $H$. sabdariffa could be attributed to its higher content of total phenol $(67,440 \mathrm{mg} / \mathrm{kg}$ gallic acid equivalent), proanthocyanidins $(729,290 \mathrm{mg} / \mathrm{kg}$ catechin equivalent) and vitamin C $(294.78 \mathrm{mg} / \mathrm{kg})$ compared to the total phenol content of $67,340 \mathrm{mg} / \mathrm{kg}$ gallic acid, proanthocyanidins $(461,340 \mathrm{mg} / \mathrm{kg}$ catechin equivalent and vitamin C $(238.26 \mathrm{mg} / \mathrm{kg})$ in A. brasiliana.

The effect of $\mathrm{pH}$ of $H$. sabdariffa extract was evident when the different concentrations of extracts $(0.1$ $-1.0 \mathrm{mg} / \mathrm{ml}$ ) used for the assay were treated with $5 \mathrm{M}$ $\mathrm{NaOH}$ to neutralize the acidity of the extracts. The DPPH activity of the neutralized extract of $H$. sabdariffa increased with increasing concentration of the extract; the $\mathrm{IC}_{50}$ was $16.75 \mathrm{mg} / \mathrm{ml}$, implying that the $\mathrm{DPPH}$ scavenging activity of $H$. sabdariffa decreased as $\mathrm{pH}$ increased from 2 to 7 . In $A$. brasiliana, however, the DPPH scavenging activity of the extract adjusted with 5 $\mathrm{M} \mathrm{NaOH}$ decreased with increasing concentration and had an $\mathrm{IC}_{50}$ of $0.229 \mathrm{mg} / \mathrm{ml}$. A. brasiliana leaves extract showed a concentration-dependent DPPH scavenging activity while $H$. sabdariffa showed a $\mathrm{pH}$ dependent DPPH scavenging activity.

The ability of ethanolic extracts of A. brasiliana and H. sabdariffa to reduce $\mathrm{Fe}^{3+}$ to $\mathrm{Fe}^{2+}$ was high (Figure 2).
A. brasiliana extract had a wider absorbance range of $0.5841-1.1012$ at $0.1-1 \mathrm{mg} / \mathrm{ml}$ than $H$. sabdariffa extract $(0.959-0.986)$ and vitamin $\mathrm{C}(0.5-0.982)$. $A$. brasiliana extract with an absorbance range of 0.58411.1012 had higher ferric ion reducing power than $H$. sabdariffa $(0.959-0.986)$ and vitamin c. This could be attributed to the higher total flavonoids $(69,034 \mathrm{mg} / \mathrm{kg}$ quercetin equivalent) and flavonols $(50,430 \mathrm{mg} / \mathrm{kg}$ quercetin equivalent) in $A$. brasiliana compared to the $57,810 \mathrm{mg} / \mathrm{kg}$ and $8,710 \mathrm{mg} / \mathrm{kg}$ quercetin equivalent for flavonoids and flavonols in H. sabdariffa. This indicated a higher ability of the $A$. brasiliana extract to reduce ferric ion than vitamin $C$ which at $0.1-1 \mathrm{mg} / \mathrm{ml}$ had an absorbance range of $0.5-0.982$. The ferric reducing power of the extracts was concentration dependent implying that they increased with increasing concentration of extracts.

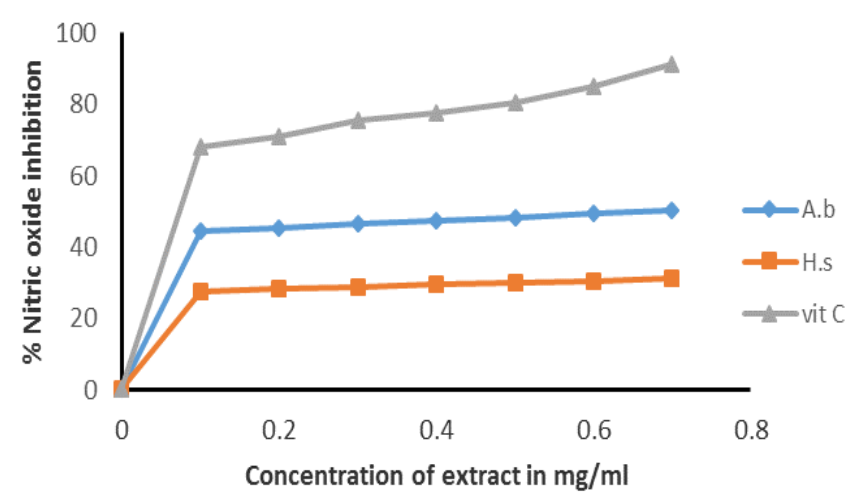

Figure 3. Nitric oxide scavenging activity of $A$ brasiliana and H. sabdariffa extracts. A. $\mathrm{b}=$ Alternanthera brasiliana extract, H. s = Hibiscus sabdariffa extract, Vit C = Vitamin $\mathrm{C}$

The nitric oxide radical scavenging activity of $A$. brasiliana and $H$. sabdariffa extracts (Figure 3) were high and dose-dependent, with $\mathrm{IC}_{50}$ of $0.675 \mathrm{mg} / \mathrm{ml}$ and $3.976 \mathrm{mg} / \mathrm{ml}$ respectively. The nitric oxide scavenging activity of $A$. brasiliana and $H$. sabdariffa extract were lower than the $\mathrm{IC}_{50}(0.322 \mathrm{mg} / \mathrm{ml})$ of vitamin C. $A$. brasiliana extract with $\mathrm{IC}_{50}$ of $0.675 \mathrm{mg} / \mathrm{ml}$ had a higher nitric oxide scavenging activity than $H$. sabdariffa calyces extract with $\mathrm{IC}_{50}$ of $3.976 \mathrm{mg} / \mathrm{ml}$. This could be attributed to its higher total flavonoid content $(69,034$ $\mathrm{mg} / \mathrm{kg}$ quercetin equivalent); higher flavonols $(50,430$ $\mathrm{mg} / \mathrm{kg}$ quercetin equivalent) content compared to the total flavonoid $(57,810 \mathrm{mg} / \mathrm{kg}$ quercetin equivalent) and total flavonols $(8,710 \mathrm{mg} / \mathrm{kg}$ quercetin equivalent) of $H$. sabdariffa. Brachado et al. (2003) identified six flavonoids in A. brasiliana leaf extract, out of which 3 inhibited lymphocyte proliferations. The high nitric oxide scavenging activity of the extracts suggests that the extracts be used in preventing inflammation, carcinomas 
and other diseases caused by nitric oxide radicals derived from cellular by-products as nitric oxide radical is known to play an important role in various inflammatory processes such as carcinomas, juvenile diabetes, multiple sclerosis, arthritis and ulcerative colitis (Hazra et al., 2008).

\section{Conclusion}

The study has revealed that $A$. brasiliana leaves and $H$. sabdariffa calyces are good sources of vitamin $\mathrm{B}_{1}, \mathrm{~B}_{2}, \mathrm{~B}_{3}$, and vitamin $\mathrm{C}$ as well as other health-promoting components such as flavonoids and phenols. The results implied that infants consuming these foods may have an improved appetite, a healthier nervous system and a higher release of energy from the complementary foods as well as be able to fight cancer better.

\section{References}

Anon. (2012). Omega-3 fatty acids. Retrieved on August 15, 2012 from EMUMAGIC website: http:// emumagic.com/omega.

Association of Official Analytical Chemists (AOAC). (2010). Official Methods of Analysis. $18^{\text {th }}$ ed. Washington, D.C.: AOAC.

Attaugwu, R.N. (2015). Improving the chemical and functional properties of maize-bambara groundnut malt and maize-cowpea malt complementary foods by food-to-food fortification. Nsukka, Nigeria: University of Nigeria, PhD. Dissertation.

Azza, A.A., Ferial, M.A. and Esmat, A.A. (2011). Physiochemical properties of natural pigments (anthocyanin) extracted from Roselle calyces (Hibiscus sabdariffa). Journal of American Science, 7(7), 445-456.

Bhasin, R., Chatterjee, K. and Ramalingam, V. (2003). Blood transfusion transmitted diseases. In Saran, R. (Ed.). Transfusion medicine-technical manual (2), p. 143 - 174. New Delhi, India.

Brachado, C., Almeida, A., Barreto, B. O., Costa, L. P., Ribeiro, L. S., Pereira, R. L., Gonclaves Koaz., V. L. and Costa, S. S. (2003). Flavonolrobinobiosides and rutinosides from Alternanthera brasiliana (Amaranthaceae) and their effects on lymphocyte proliferation in vitro. Journal of Brazilian Chemical Society, 14(3), 1 - 5.

Christian, K.R., Nair, M.G. and Jackson, J.C. (2006). Antioxidant and cyclooxygenase inhibitory activity of sorrel (Hibiscus sabdariffa). Journal of Food Composition and Analysis, 19, 778-783.
Dewey, K.G. and Brown, K.H. (2003). Update on technical issues concerning complementary feeding of young children in developing countries and implications for intervention programs. Food and Nutrition Bulletin, 24(1), 5 - 28.

Duarte, M.R. and Debur, M.C. (2004). Characteristics of the leaf and stem morpho-anatomy of Alternanthera brasiliana (L) O. Kuntze, Amaranthaceae. Brazilian Journal of Pharmaceutical Sciences, 40(1), 3-9.

Elija K., Vaishali, B., Manik, M.K., Deshpande, N.R. and Kashaikar, R.V. (2010). Spectroscopic determination of total phenol and flavonoid contents of Ipomoea carnea. International Journal of Chemical Technology Research, 2(3), 1698-1701

Ferrari, C. K. B. 2004. Functional Foods, Herbs and Nutraceutical towards Biochemical Mechanisms of Healthy aging. Biogerontology, 5, 275-289.

Gibbs, M.M. (2010). Manufactured complementary foods for infant and young child feeding in Asia: micronutrient adequacy and improvement. Dunedin, New Zealand: University of Otago, MSc. Thesis.

Harborne, J.B. (1973). Phytochemical Methods a Guide to Modern Techniques of plant Analysis, New York: Chapman and Hall.

Hazra, B., Santana, B. and Nripendranath, M. (2008). Antioxidant and free radical scavenging activity of Spondias pinnata. Journal of BMC Complementary and Alternative Medicine, 8, 63.

Kong, J. M., Chia, L. S., Goh, N. K., Chia, T. F. and Brouillard, R. (2003). Analysis and biological activities of anthocyanin. Phytochemistry, 64, 923-933.

Kumaran, A. and Karunakaran, F.J. (2007). In vitro antioxidant activities of methanol extracts of phyllantus species from India. Life Technology, 40, $344-352$.

Lin, T-L., Lin, H.H., Chen, C.C., Lin, M.C., Chou, M.C. and Wang, C.J. (2007). Hibiscus sabdariffa extract reduces serum cholesterol in men and women. Nutrition Research, 27, 140-145.

Liyana-Pathiranan, C.M. and Shahidi, F. (2005).

Antioxidant activity of commercial soft and hard wheat (Triticumaestivum.L.) as affected by gastric $\mathrm{pH}$ conditions. Journal of Agriculture and Food Chemistry, 53, 2433 - 2440.

Lutter, C.K. and Dewey, K.G. (2003). Proposed nutrient composition for fortified complementary foods. The Journal of Nutrition 133(9), 3011s - 3020s.

Luvonga, W.A., Njoroge, M.S., Makokha. A. and Ngunjiri, P.W. (2012). Chemical characterization of Hibiscus sabdariffa (Roselle) calyces and evaluation of its functional potential in the food industry. 
Retrieved on September 12, 2016 from JKUAT

Website: Journal. Jkuat.ac.ke/index.php/jscp/article/ download/745/687.

Middleton, E., Kandaswami, C. and Theonarides, T.C. (2000). The effects of Plant Flavonoids on Mammalian Cells: Implications for Inflammation, Heart Disease, and Cancer. Pharmacological Reviews, 52, $673-751$.

Ordoñez, A.A.L., Gomez, J.D., Vattuone, M.A. and Isla, M.L. (2006). Antioxidant activities of sechiumedule. Food Chemistry, 97, 452 - 458.

Oyedemi, S.O., Bradley, G. and Afolayan, A.J. (2010). In-vitro and vivo antioxidant activities of aqueous extract of strychnos henningsii Gilg. Retrieved on June 4, 2014 from ACADEMICJOURNALS website: http://www. academicjournals.org/ajpp.

Pearson, D. (1976). Laboratory techniques in food and analysis. London: Butterworth and Company Publishing Ltd.

Saawan, K., Pradeep, S., Garima, M., Saurabb, S., Jha, K.K. and Khosa, R.L. (2011). Phytopharmacological review of Alternanthera brasiliana (Amaranthaceae). Asian Journal of Plant Science and Research, 1(1), 41-47

Snell, F.D. and Snell, C.T. (1953). Colorimetric methods of analysis. Vol. 3, p. 165 - 166. New York: D. Van Nostrand Company Incorporated.

Sun, J.S., Tsuang, Y.W., Chen, J.J., Huang, Y.S. and Lu, F.J. (1998). An ultra-weak chemiluminescence study on oxidative stress in rabbits following acute thermal injury. Burns, 24, $225-231$.

Vladimir-Knezevic, S., Blazekovic, B., Stefan, M.B., Alegro, A., Koszegi, T. and Petrik, J. (2011). Antioxidant activities and polyphenolic contents of three selected micromeria species from Croatia. Molecules, 16 (2), 1454 - 1470

WHO. (2003). Feeding and Commercialization of infants and young child guidelines for the WHO European region with emphasis on the former Soviet Union. European Series, No. 87, p. 1-296. Denmark: WHO Regional Publications

WHO/UNICEF (2003). Global strategy for infant and young child feeding. WHO/UNICEF. Retrieved on March 3, 2012 from WHO Website: http:// www.who.int/child_adolescent_health/ documents/9241562218/ en/index.html.

Wolfe, K., Wu, X. and Liu, R.H. (2003). Antioxidant activity of apple peels. Journal of Agriculture and Food Chemistry, 51, 609 - 614

Wong, P.K., Yusuf, S., Ghazali, H.M. and Man, Y.B.C. (2002). Physio-chemical characteristics of Roselle (Hibiscus sabdariffa L.). Journal of Nutrition and
Food Science, 32, 68-73.

Yen, G. and Chen, H. (1995). Antioxidant activity of various tea extract in relation to their antimutagenicity. Journal of Agriculture and Food Chemistry, 43, 7-32.

Yi-Fang, C, Jie S., Xian-Hong, W.W and Rui-Hai, L. (2002). Antioxidant and Antiproliferative activities of common vegetables. Review Journal of Agriculture and Food Chemistry, 50, 6910-6916. 